\title{
Understanding the Differences Between Vendor Types in Local Governance
}

American Review of Public Administration

\section{Scott Lamothe' and Meeyoung Lamothe'}

\begin{abstract}
It is commonly posited that for-profit, nonprofit, and other government vendors have fundamental differences, which make one or the other the superior choice depending on the circumstances of service delivery. Past research, focusing on service and market characteristics, finds support for this proposition. In this article, we investigate not only the typical theoretical expectations regarding vendor traits, service characteristics, and market conditions associated with the sectors, but also the presumed trustworthiness and management practices that are argued to differentiate them in an effort to better understand the roles played by each in local government contracting. Our findings indicate that as expected, nonprofits are most commonly employed when dealing with hard to define, "soft" services with weak markets. However, contrary to expectations, nonprofits are not generally considered more trustworthy than for-profits and are not managed more "loosely" (i.e., more ambiguous contracts, more discretion exercised in sanctioning) than their for-profit peers. Rather, public vendors seem to be the most trusted and are managed less rigidly than contractors from the other sectors.
\end{abstract}

\section{Keywords}

contracting, vendor ownership, local governance, service delivery

It is common in the local government contracting literature to argue that sector matters; that is, to posit that for-profit, nonprofit, and other governmet vendors have fundamental differences, which make one or the other the superior choice depending on the circumstances of service delivery. Scholars adopt various theoretical frameworks to explain vendor preference in contracting. Public choice theorists generally favor for-profit firms for improving efficiency and promoting innovation in local service delivery (Osborne \& Gaebler, 1992; Savas, 1987). A key to the successful use of for-profit vendors is for local governments to become "smart buyers" (Kettl, 1993) so as to reap the benefits that markets offer (Savas, 2000). For-profit vendors are deemed less ideal when competitive markets do not exist (Kettl, 1993). In addition, transaction cost economics suggests that the benefits gained from using for-profit vendors can be diminished when services are difficult to define and vendor performance is challenging to assess (Brown \& Potoski, 2003a; Ferris \& Graddy, 1986; Lamothe \& Lamothe, 2006; Lamothe, Lamothe, \&

\footnotetext{
'University of Oklahoma, Norman, OK, USA

Corresponding Author:

Scott Lamothe, University of Oklahoma, 455 West Lindsey Street, Norman, OK 730 I9, USA.

Email: slamothe@ou.edu
} 
Feiock, 2008). Nonprofits and other governments are favored in these circumstances as the nondistributive legal constraints to which they are subject and the publicness embedded in these types of organizations promote their faithfulness as contracting agents (Brown \& Potoski, 2003a; Hefetz \& Warner, 2012; Stein, 1990). Furthermore, other government contractors are also appealing where economies of scale can be achieved and equity can be promoted through public market solutions (Bel \& Fageda, 2006; Warner, 2006; Warner \& Hebdon, 2001).

Nonprofits seem to be preferred over the other sectors for the delivery of social services (Ferris \& Graddy, 1986). Government failure theory (Weisbrod, 1988) contends that nonprofit organizations are suitable choices for providing human services that benefit groups with relatively narrowly defined needs or preferences in community settings (see also similar discussions from Bellah, Madson, Sullivan, Swidler, \& Tipton, 1985; Berger \& Neuhaus, 1977; Smith \& Lipsky, 1993). Nonprofits are also argued to have comparative advantages over the government and market for delivering services to socially undesirable groups because their actions are less restrained by ownership-driven accountability (i.e., preferences of voters and shareholders; Billis \& Glennerster, 1998). While the literature on vendor preference mainly focuses on procurement (i.e., choosing vendors once principal governments decide to buy services), recent scholarly efforts extend inquiries into examining whether there are sectoral differences in managing and overseeing contracts as well (Amirkhanyan, 2010; Andrew \& Entwistle, 2010; Marvel \& Marvel, 2007, 2008, 2009). Again, theory separates nonprofit and other government contractors from their for-profit counterparts and generally predicts that principal governments treat these two presumably more trustworthy vendor types with less oversight and more discretion.

The main purpose of our study is to comprehensively examine the validity of these existing claims about vendor ownership in contracting. In so doing, we investigate not only the typical theoretical expectations regarding vendor traits, service characteristics, and market conditions associated with the sectors, but also the presumed trustworthiness and management practices that are argued to differentiate them. Examining vendor ownership in a multivariate environment, including a direct test of the sector-based trust assumption, is important because there is a possibility that not all posited factors are coherently and independently identified with one or the other sectors. Recent empirical findings suggest this possibility by reporting no meaningful differences between nonprofits and for-profits on several dimensions (for example, Andrews \& Entwistle, [2010] find them nondifferentiable on performance; Amirkhanyan, [2010, p. 750] reports that public managers "unequivocally reject the proposition that ownership matters"; Lamothe \& Lamothe, [2010] find no difference regarding adherence to contract terms). To comprehensively investigate sector differentiation, we administer our own survey of local jurisdictions that deliver hard and soft services through outsourcing and use multinomial logit to estimate the model.

Our findings suggest a significant gap between theory and practice in our understanding of vendor ownership and related managerial behaviors. Public managers do have differing perceptions about nonprofit and for-profit vendors in terms of their community ties, the characteristics of the services they deliver, and the competitiveness of the markets in which they operate. Such segregation, however, does not seem to extend to the degree of trust they display toward them, nor to lead to differential treatment regarding writing contracts and enforcing sanctions in the occurrence of noncompliance. Interestingly, this is not the case when local jurisdictions rely on their neighboring governments to deliver services - principal governments seem to trust their public vendors more so than private vendors and consequently use only minimal safeguards when preparing and managing such contracts. Below we discuss the theoretical expectations regarding vendor ownership, develop hypotheses and report the findings from our model. We conclude by reviewing the implications of our findings. 


\section{Theoretical Expectations Concerning Vendor Ownership}

\section{Vendor Traits}

Scholars derive core differences among the sectors based on their legal and organizational foundations because these frameworks provide essential clues as to the general goals and accountability structures of vendor organizations.

Trust. Both public choice theorists and transaction costs analysts argue that the sectoral differences posited between nonprofit and other government vendors and their for-profit counterparts originate from the different legal and organizational boundaries within which these sectors operate; specifically, nonprofits and governments are not allowed to distribute profits to owners or shareholders. Scholars often argue that the inability of nonprofits and public organizations to transfer surpluses to private interests makes them more trustworthy contracting partners because they have fewer incentives to cut corners or participate in other opportunistic behaviors to the detriment of principal governments (Brown, Potoski, \& Van Slyke, 2006). Besides the legal limitations, the supposed trustworthiness of these two sectors as contract agents can be traced to the notion that government workers (Brewer \& Selden, 1998; Rainey, 1982) and nonprofit employees (Leete, 2006; Light, 2004) are more publicly minded than their for-profit peers; that is, they are more likely to have joined their organizations in pursuance of contributing to the public good rather than simply in search of personal gain. Taken together, the literature recognizes nonprofit and public organizations as inherently more trustworthy than for-profit firms.

Scholars further distinguish other governments from nonprofits as particularly reliable and credible contracting partners for local governments (Andrew \& Entwistle, 2010; Stein, 1990; Warner \& Hefetz, 2002). Although nonprofit and other government vendors are argued to share such similarities as nondistributive legal constraints, public-minded personnel, and missionoriented behavior, other government contractors are set apart from nonprofit organizations in that as public units, they share the same organizational characteristics and are subject to the same political scrutiny that contracting governments face (Brown 2008; Marvel \& Marvel, 2007; Stein, 1990; Van Slyke, 2003) and thus are considered to be inherently more publicly accountable, even when there is minimal to no monitoring by principal governments. A deeper level of conviction as to why other government contractors are unlikely to be opportunistic also comes from the fact that governments, in general, have more stable revenue sources (for example, through taxes and fees) to maintain their financial security than nonprofits who "may enter service markets for fiscal survival" (Brown, 2008, p. 368). Amirkhanyan (2010, p. 747) reports how local administrators perceive nonprofit contractors to be as "fiscally aggressive" as their forprofit counterparts to protect their bottom lines even while they see nonprofits' missions being more generally aligned with those of contracting governments.

In sum, we expect that local governments consider other governments as the most trustworthy contracting partners (H1) while trusting nonprofits more than their for-profit counterparts in terms of fulfilling contractual obligations without engaging in opportunism (H2).

Community ties. Unlike the presumed trustworthiness shared by nonprofit and other government contractors, the concept of "community ties" appears to be uniquely associated with the former type of vendors. Nonprofits' strong connections to the communities are frequently recognized among scholars. As such, Smith and Lipsky (1993, p. 22) call them "manifestations of community" as local volunteers often make up large portions of nonprofit workforces as well as their governing boards (Boris \& Steuerle, 2006; Smith \& Lipsky, 1993; Worth, 2009). Other scholars point out the long history of community-based nonprofit organizations delivering human services in the absence of government intervention (Salamon, 1995; Young, 2006). When "government became an active participant in the provision of human services . . . service provision was typically accomplished via contracting with these existing [nonprofit] agencies" (Sclar, 
2000, p. 125; see also Smith \& Lipsky, 1993 for a similar narrative). It should be noted that claiming close associations to the communities they serve is not entirely monopolized by nonprofit organizations as private business traces its philanthropic roots back to the 19th century in the form of community-based charitable contributions (Hall, 1989; Young, 2006). Nonetheless, we expect that nonprofits distinguish themselves as holding much stronger ties to the communities than for-profit or other government vendors (H3).

\section{Service Environments}

Above, we discuss how vendors' legal and organizational characteristics and internal governance structures tend to spawn varying degrees of trustworthiness by sector. These are internal attributes closely related to the ownership status of vendors. The literature also identifies external conditions that separate vendors. These conditions are closely related to the characteristics of the services each sector produces and the market and political environments to which they are often subject.

Risks associated with services. Scholars frequently employ Williamson's (1985) measurement difficulties and asset specificity dimensions based on the transaction costs economics (TCE) framework to characterize the nature of services (Brown \& Potoski, 2003a, 2005; Ferris \& Graddy, 1991; Lamothe et al., 2008). By theory, for-profit firms are preferred for hard services that are easy to define, measure, and monitor while nonprofits and public vendors are favored for soft types whose tasks are ambiguous and performance is difficult to evaluate. Theory also chooses the latter types of vendors for delivering services that have the potential for "hold up" (Levin \& Tadelis, 2010) where incumbents are advantaged by investment in specific assets or because of the need to customize service delivery. Contract failure theorists predict an increase in "both the incentive and opportunity to take advantage of customers" (Hansmann, 1987, p. 29) if these types of services are provided by for-profit firms (see also Moe, 1996; Steinberg, 2006 for discussions of contract failure theory). For-profits might also have incentives to limit access (Ferris \& Graddy, 1986). For example, in social services they might engage in "cream skimming" in an effort to avoid cases that would require high resource commitments or have low probabilities of success (Smith \& Lipsky, 1993). Nonprofits lack this motivation and may concentrate their resources on delivering quality products. In fact, Schlesinger and Gray (2006) report nonprofit hospitals being consistently more accessible to unprofitable clients and nonprofit nursing homes providing better care to vulnerable populations who do not have vocal advocates representing their interests.

Likewise, other government vendors as soft service deliverers enjoy the same perception of embedded faithfulness and quality, but also are regarded as particularly reliable vendors that ensure "continuity and stability of services" to the constituents of contracting governments, which is an important priority public managers pursue (Andrew \& Entwistle, 2010, p. 681). Unlike nonprofit service providers, however, other governments are likely choices for easily measurable hard services as well when only limited numbers of private vendors are available and using public markets through multijurisdictional cooperation is an option to achieve economies of scale (Bel \& Fageda, 2006; Warner \& Hebdon, 2001).

As a result, we expect that nonprofits are most likely to be associated with challenging-to-assess and highly asset-specific soft services (H4). Public vendors may deliver a mixture of hard and soft services for the reasons discussed above and, hence, while we expect public contractors to more closely associated with these types of services, the separation between governmental and for-profit vendors might not be as pronounced as the difference between nonprofits and for-profits (H5).

Service market conditions. Public choice theorists and privatization advocates argue that the injection of market-like discipline into public service delivery systems will lead to an increase in 
efficiency and consumer choice (Dunleavy \& Hood, 1994; Hood, 1991; Savas, 2000). Competition is the key underlying theoretical condition to be met to make this assertion plausible because it is competition that forces potentially self-interested and profit-seeking vendors to be responsive to buyers' preferences and bid close to their true production costs to win contracts (DeHoog, 1984; Kettl, 1993). In the presence of competition, for-profit firms are favorite choices for service delivery because of their strong incentives to be efficient (Savas, 1987, 2000). Unfortunately, failure to form competitive and viable markets commonly occurs in quasi-market systems (Hirsch, 1991; Lowery, 1998). Competition is especially lacking in human service contracting (DeHoog, 1984; Lamothe \& Lamothe, 2009; Sclar, 2000; Smith \& Lipsky, 1993; Van Slyke, 2003) and is considered counterproductive when services require integrated delivery systems (Milward \& Provan, 2000). Nonprofits are natural fits for these types of markets. As discussed in the previous section, limited private markets are also likely to lead to public market utilization, especially with regard to small and rural municipalities relying on county governments to deliver needed services (Warner \& Hebdon, 2001). We thusly predict a nexus between limited vendor markets and nonprofit and other government contractors while expecting for-profit vendors to be more commonly associated with competitive markets (H6).

Citizen interest in services. Some services are likely of more concern to citizens than others. For example, the average resident probably cares more about the quality and quantity of police services in his/her jurisdiction than how public parking lots are managed. This reality may affect the behavior of public managers, for as Bartels (1991, p. 457) puts it: "[t]he appeal of representative democracy hinges on the responsiveness of elected politicians to the preferences and interests of their constituents." This logic applies to appointed managers as well, as they serve at the pleasure of their elected bosses. Prescribing to this line of reasoning, public management scholars argue that government administrators will try to maintain as much command as possible over such services. Levin and Tadelis (2010) find that "sensitive" services are more likely to be produced in-house than through contractual arrangements and argue this is because "cities want control over [such] services" (529). Similarly, Hefetz, and Warner (2012) posit that when services of particular interest to constituents are outsourced, public or nonprofit vendors, as opposed to forprofits, should be the contractors of choice owing to communities having more influence with such entities. They find some support for this assertion-for-profit contracting is less likely for those services that public managers deem to be of greatest relevance to the residents of their jurisdictions. Based on the above, we hypothesize that services that are deemed to be of high interest to citizens should be more commonly contracted to other government and nonprofit vendors, and less likely to use for-profit entities (H7).

\section{Contract Features and Management Styles}

The contracting literature largely focuses on initial vendor selection when examining ownership differences (Brown \& Potoski, 2003a; Hefetz \& Warner, 2012; Lamothe et al., 2008). More recently, researchers have turned their attention to examining whether ownership matters in managing vendors once they are recruited. Scholarly concerns are centered on the types and intensity of oversight directed toward vendors (Amirkhanyan 2010; Marvel \& Marvel, 2007, 2008, 2009). Marvel and Marvel (2009, p. 189) argue that high-powered incentives and sanctions such as monetary awards and penalties, as well as contract extension and suspension, are suitable for "managing contracts with market-driven firms" to promote efficiency and keep the behavior of profit-seeking agents in-line with the goals of principals. Adhering only to monetary and other material incentives and penalties to control agents, however, may result in suboptimal achievement since, while "what gets measured gets done" (Marvel \& Marvel, 2009, p. 187), principal governments' policy goals can easily be compromised given the informational asymmetries 
favoring agents (Heckman, Heinrich, \& Smith, 2002; Heinrich, 2007; Holmstrom \& Milgrom, 1991). Marvel and Marvel (2009) also contend that such high-powered management strategies are less transferable and less effective when applied to nonprofit and other government contractors as they may serve as a hindrance to long-term, cooperative relationship building processes based on trust. Stewardship theory argues that adopting low-powered, nonmonetary incentives such as informal discussions, technical assistance, and public recognition/reprimand are sufficient to keep these types of vendors controlled and to elicit quality performance (Marvel \& Marvel, 2009; Van Slyke, 2007).

Regarding sectoral differences as to the extent of oversight, Marvel and Marvel (2007) report that governments tend to monitor substantially less when outsourcing to public and nonprofit agents while supervising more intensely when using their own employees or dealing with forprofit contractors. They explain that the lack of oversight for public vendors might be because governments simply transfer quality control responsibilities to fellow governmental units whom they trust to perform their own internal monitoring. Other scholars offer similar arguments as to auditing advantages (Van Slyke, 2003) and deference in monitoring (Lamothe \& Lamothe, 2010) when using public vendors.

Marvel and Marvel (2007) argue that strong goal congruence exists between governments and nonprofits and contend that such mission alignment potentially results in insufficient monitoring of nonprofit contractors. However, recent empirical findings are more nuanced in terms of nonprofit - for-profit differences. For example, Amirkhanyan (2010) reports no perceptual differences between these two vendor types when public managers are asked about whether ownership matters to them in managing contracts. What appears to set them apart is not so much their sectors or origin, per se, but the nature of the services they deliver. It may not be that monitoring intensity varies by vendor type so much as there might be variance in the methods of monitoring owing to the characteristics of the services (e.g., hard service monitoring may make greater use of measurable indicators, whereas soft service monitoring might be more qualitative and process-oriented in nature).

Based on these discussions, we anticipate post procurement management and oversight activities to differ for public and private vendors, not only because of their differing legal and organizational characteristics, but also owing to the fact that public entities share similar political and managerial traits. Specifically, we predict generally lower levels of administrative controls in both ex ante and ex post oversight activities when governments rely on public vendors (H8). We do not expect this to be the case when governments contract out to nonprofit or for-profit vendors, although managerial controls might be less intensive when involving the former type of vendors (H9).

\section{Data Collection and Research Design}

To assist us in testing the differences between for-profit, nonprofit, and other government vendors, we conducted a survey through the purchase of a contact list of 2,000 jurisdictions from the International City/County Management Association (ICMA). ICMA's database contains contact information for approximately 10,300 municipalities and counties in the United States. Of these, 1,519 governmental units have populations of 50,000 or greater (660 cities and 859 counties) and 8,751 governmental units have populations of less than 50,000. So as to maximize our chances of gathering a good mix of vendor types, we chose to limit our sample to only those jurisdictions with populations of 25,000 or more, for as Levin and Tadelis (2010) find, larger jurisdictions are more likely to provide a wider array of services through a variety of arrangements. Surveys were sent to each unit in our sample during January of 2010 with reminder postcards sent in early February. Toward the end of February, we sent the survey package to all nonresponding jurisdictions in the hopes of receiving additional responses. ${ }^{2}$ 
We asked each respondent to answer questions for two services of their choosing that they deliver through contracted arrangements - one from a list of hard services and one from a list of soft services, as defined by ICMA's classifications of public works/transportation and health and human services, respectively (see Appendix A for the lists). The bulk of our questions take the form of 5-point, ordered scales where respondents are asked to mark the point between two opposing statements that they feel most accurately represents their beliefs or the circumstances of their jurisdictions with regard to the specific contract in question. For example, to ascertain competitiveness of the vendor market, respondents were asked to choose between $1=$ There are many vendors in the market available to replace the incumbent to $5=$ There are very few vendors in the market to replace the incumbent (please see Appendix B, which defines the codings of the variables used in the analysis, for the verbiage for each of the queries). ${ }^{3}$ As such, each jurisdiction can show up in our data two times, with each case representing a specific governmentservice pair.

In the end, we received responses from 359 jurisdictions, for a response rate of $18.0 \%{ }^{4}$ Of the responding jurisdictions, 69 indicate they do not contract for either type of service and 17 include no suitable information. In addition, some cases are missing data on variables relevant to our analyses. Because of these limitations, the number of jurisdictions included in our model is 248 . As we ask for information on two services, the maximum number of cases possible is 496 . However, many jurisdictions only reported information for one service (most commonly the hard service), usually indicating they do not contract for the other type. So, in the end, number of cases included in our analysis is 335 (with a total of 215 hard and 120 soft service cases).

As with any sample, there are questions as to the representativeness of our data. Turning to Appendix C, we see that our dataset vastly oversamples jurisdictions with larger populations. As mentioned above, this is by design. However, it still has implications for the generalizability of this study. Our data are dominated by jurisdictions in the 50,000 to 249,999 population range, which is not representative of the overall distribution of municipalities in the country. Thus, our findings are more relevant to such midrange to larger jurisdictions. Our findings may not translate well to small jurisdictions (especially those with populations under 10,000). We also undersample north central and oversample western jurisdictions. It is not clear what, if any, implications there are for interpreting our results, but readers should be aware of this concern. Finally, as always seems to be the case with ICMA-related data, council-manager forms of government are overrepresented. This could call into question the generalizability of our findings as there might be reason to believe that professional managers' perceptions of contracting environments might vary systematically from elected public officials owing to differing educational backgrounds and career expectations and pressures. ${ }^{5}$ Having described our data collection process, we now turn to describing the measurement of the variables in our model and the analytic technique employed.

\section{Variable Measurement}

Our dependent variable, Vendor type, is a categorical measure that identifies for-profits, nonprofits, and other governments. When discussing our independent variables, unless otherwise stated, all are 5-point ordered with the variable descriptions explaining what the high scores indicate (readers are directed to Appendix B for a more comprehensive review of the codings of all variables included in the analysis).

Trust measures the extent to which the vendor is perceived to fit the following description: "We trust this vendor to fulfill its obligations even when it is not being watched." Community ties accounts for how strongly grounded in the community contractors are perceived to be. Measurement difficulty is an additive composite of two 5-point indicators (alpha $=0.798$ ) capturing the difficulty associated with defining service tasks and performance measures. Asset 
specificity is Brown and Potoski's (2003a) measure (see also Carr, LeRoux, \& Shrestha, 2009) and accounts for the extent to which service production requires specialized investment of assets. Few vendors denotes the competitiveness of the service market (i.e., are there too few potential vendors?). Citizen interest is borrowed from Hefetz and Warner (2012) and captures not only how concerned citizens are with the quality of the service delivery, but also how interested they are in the process as well.

We tap into how contracts are managed through the use of three variables. Contract features is the sum of three 5-point measures (alpha $=0.753$ ) that determine if contracts are generally not rebid unless the incumbent has problems, deliverables are ambiguous, and the contract lacks explicit sanction clauses. Contacts and coordination summarizes if such activities are common during the contract implementation phase. The last variable, Use of discretion in sanctioning, measures if "negotiation often takes place without formal sanctioning and contract terms may be altered as a result." In all cases, it is our expectation that public vendors will be associated with the most lax styles of management and for-profits the most stringent. Nonprofits should hold a middle ground. Therefore, as high scores on both Contract features and Use of discretion in sanctioning represent less rigid approaches, other government contractors should be associated with higher scores on these variables while for-profits should tend toward lower values, with nonprofits falling somewhere between. However, high scores on Contacts and coordination represent active, "hand-on" management, leading us to posit that high scores should indicate forprofit contracting, low scores other governments, and, once again, middling scores pointing toward nonprofits.

We also include a series of control variables, not previously discussed. Professional administrator is dichotomous and codes one if the jurisdiction uses a council-manager form of government, which may be associated with higher levels of capacity (Brown \& Potoski, 2003b) and professionalism. This, in turn, might systematically impact how jurisdictions match services and vendors. Jurisdiction size is accounted for by including the census estimate for the population in 2008 (Population, 2008). We feel this variable is needed because larger jurisdictions should have a greater selection of vendors and types of vendors to choose from than their smaller counterparts. We also control for level of government through the use of a dummy variable identifying counties, as it seems likely that counties should be less likely to contract with other governments than smaller jurisdictions that are trying to achieve economies of scale. Furthermore, county governments may also be more likely to contract with nonprofits as this level of government is often highly involved in the delivery of social services. Finally, Performance indicates that "this vendor has been performing very much above expectations." While it is important to include this measure as it might be related to other aspects that differentiate between vendors, such as levels of trust, it also is serves as a rudimentary test of the proposition than specific sectors are associated with superior performance. See Table 1 for the descriptive statistics for all of the variables included in the analysis (please note that the dependent variable, Vendor type, is broken down into its dichotomous components, for-profit, nonprofit, and other government, for the sake of this Table).

As our dependent variable is categorical, multinomial $\operatorname{logit}^{6}$ is an appropriate choice for estimation. ${ }^{7}$ Taken together, the above lead to the following equation:

Vendor type $=\mathrm{b}_{0}+\mathrm{b}_{1}$ Trust $+\mathrm{b}_{2}$ Community ties $+\mathrm{b}_{3}$ Measurement difficulty $+\mathrm{b}_{4}$ Asset specificity $+b_{5}$ Few vendors $+b_{6}$ Citizen Interest $+b_{7}$ Contract features $+b_{8}$ Contacts and coordination $+b_{9}$ Use of discretion in sanctioning $+b_{10}$

Professional administrator $+\mathrm{b}_{11}$ Population 2008 $+\mathrm{b}_{12}$ County $+b_{13}$ Performance + e. 
Table I. Descriptive Statistics for Variables Included in the Analysis.

\begin{tabular}{lllll}
\hline Variable & Mean & $\begin{array}{c}\text { Standard } \\
\text { Deviation }\end{array}$ & Minimum & Maximum \\
\hline Dependent variable by category & & & & \\
$\quad$ For-profit & 0.636 & 0.482 & 0.000 & 1.000 \\
$\quad$ Nonprofit & 0.269 & 0.444 & 0.000 & 1.000 \\
$\quad$ Other government & 0.096 & 0.294 & 0.000 & 1.000 \\
Variables of Interest & & & & \\
$\quad$ Trust & 3.791 & 1.073 & 1.000 & 5.000 \\
Community ties & 3.612 & 1.225 & 1.000 & 5.000 \\
Measurement difficulty & 4.566 & 2.178 & 2.000 & 10.000 \\
Asset specificity & 3.135 & 0.529 & 2.140 & 4.220 \\
Few vendors & 3.518 & 1.372 & 1.000 & 5.000 \\
$\quad$ Citizen Interest & 3.076 & 0.514 & 1.500 & 4.000 \\
Contract features & 7.549 & 3.487 & 3.000 & 15.000 \\
Contracts and coordination & 3.975 & 1.082 & 1.000 & 5.000 \\
$\quad$ Use of discretion in sanctioning & 3.143 & 1.163 & 1.000 & 5.000 \\
Controls & & & & \\
$\quad$ Professional administrator & 0.737 & 0.441 & 0.000 & 1.000 \\
Population 2008 & 0.240 & 0.809 & 0.025 & 9.862 \\
$\quad$ County & 0.490 & 0.501 & 0.000 & 1.000 \\
$\quad$ Performance & 3.888 & 0.746 & 2.000 & 5.000 \\
$N$ = 335 & & & & \\
\hline
\end{tabular}

\section{Results}

The results of our analysis are located in Table 2. Overall, the model fit is good with the chisquared statistic significant at less than one percent and a proportional reduction in error of $26.3 \%{ }^{8}$

Overall, the results suggest that a higher level of trust and laissez-faire management styles are likely to be associated with government contractors while nonprofit and for-profit vendors are not significantly differentiated on either dimension. A particularly striking difference between governmental and private vendors is that public managers seem to use few ex ante control mechanisms when outsourcing services to fellow government agencies. That is, their contract documents tend to be more vaguely written with fewer specifics about deliverables, performance measures, or sanctions. This is not the case when governments write contracts with nonprofits despite their supposed goal alignment with the public sector. Nonprofits, however, are clearly distinguished from governmental and for-profit contractors in terms of their strong community ties and measuring difficulties related to the types of services they deliver. Nonprofits are further separated from for-profits and public vendors in terms of higher levels of asset-specificity and tend to have more limited vendor markets than their for-profit peers. Interestingly, principal governments do not seem to differentiate the sectors at all when deciding how frequently they coordinate with their vendors or how strictly they enforce formal sanction clauses toward noncompliant or nonperforming vendors. Government and for-profit vendors share some other contracting characteristics as well. For example, there appears to be only an insignificant gap between these two types of vendors in terms of service measurability and market characteristics and citizen interest, suggesting that local governments tend to use public as well as for-profit markets to deliver a variety of hard services that affect residents' daily lives. 
Table 2. What Differentiates the Vendor Types?

\begin{tabular}{|c|c|c|c|c|c|c|}
\hline \multirow{2}{*}{$\frac{\text { Independent variables }}{\text { Variables of interest }}$} & \multicolumn{2}{|c|}{$\begin{array}{l}\text { For-profit (as reference) } \\
\text { versus nonprofit }\end{array}$} & \multicolumn{2}{|c|}{$\begin{array}{l}\text { For-profit (as reference) } \\
\text { versus other government }\end{array}$} & \multicolumn{2}{|c|}{$\begin{array}{l}\text { Nonprofit (as reference) } \\
\text { versus other government }\end{array}$} \\
\hline & $b$ & $s e^{a}$ & $b$ & se & $b$ & se \\
\hline Trust & $(+)^{b} 0.126$ & 0.228 & $(+) 0.684 * *$ & 0.348 & $(+) 0.558^{*}$ & 0.331 \\
\hline Community ties & $(+) 1.314^{*} * *$ & 0.203 & $(+/-) 0.614 * * *$ & 0.209 & $(-)-0.700 * * *$ & 0.244 \\
\hline $\begin{array}{l}\text { Measurement } \\
\text { difficulty }\end{array}$ & $(+) 0.300 * * *$ & 0.099 & $(+) 0.062$ & 0.111 & $(-)-0.238 * *$ & 0.112 \\
\hline Asset specificity & $(+) 2.596$ **** & 0.514 & $(+) 1.662^{* * * *}$ & 0.584 & $(-)-0.935^{*}$ & 0.554 \\
\hline Few vendors & $(+) 0.448^{* *}$ & 0.186 & $(+) 0.290$ & 0.224 & $(+/-)-0.158$ & 0.249 \\
\hline Citizen interest & $(+) 1.814^{* * * *}$ & 0.392 & $(+)-0.649$ & 0.515 & $(+/-) 1.165^{* *}$ & 0.552 \\
\hline Contract features & $(+) 0.041$ & 0.071 & $(+) 0.314^{* * *}$ & 0.087 & $(+) 0.273^{* * *}$ & 0.086 \\
\hline $\begin{array}{l}\text { Contacts and } \\
\text { coordination }\end{array}$ & $(-) 0.099$ & 0.177 & $(-)-0.182$ & 0.193 & $(-)-0.280$ & 0.194 \\
\hline $\begin{array}{l}\text { Use of discretion } \\
\text { in sanctioning }\end{array}$ & $(+)-0.065$ & 0.189 & (+) 0.019 & 0.224 & $(+) 0.084$ & 0.216 \\
\hline \multicolumn{7}{|l|}{ Controls } \\
\hline $\begin{array}{l}\text { Professional } \\
\text { administrator }\end{array}$ & 0.483 & 0.495 & $(+)-0.179$ & 0.529 & $(+)-0.66 \mathrm{I}$ & 0.577 \\
\hline Population 2008 & $0.378^{* * *}$ & 0.130 & $(+)-0.533$ & $1.04 \mid$ & $(+)-0.911$ & 1.034 \\
\hline County & -0.156 & 0.377 & $(+)-0.86 I^{*}$ & 0.464 & $(+)-0.705$ & 0.474 \\
\hline Performance & -0.122 & 0.332 & $(+)-0.064$ & 0.356 & $(+) 0.058$ & 0.357 \\
\hline Constant & $-|2.96| * * *$ & 2.196 & $(+)-12.736 * * *$ & 2.569 & (+) 0.224 & 2.655 \\
\hline \multicolumn{7}{|c|}{$\begin{array}{l}N=335 \text { cases } / 248 \text { jurisdictions } \\
\chi^{2}=126.84^{* * * *}\end{array}$} \\
\hline
\end{tabular}

${ }^{a}$ Robust standard errors clustered on jurisdiction (see White 1980).

${ }^{b}$ Hypothesized direction of relationship.

$*_{p}<0.10$. $*_{p}<0.05$. $* * * p<0.0$ I (two-tailed).

Turning to specifics, we see in Table 2 that the Trust related hypotheses are only partially supported. Contrary to expectations Trust is not particularly helpful in differentiating between nonprofit and for-profit contractors. Only other government vendors are perceived to be more trustworthy than the other two types of contract agents $(b=0.684, p=0.049$ for the comparison with for-profits and $b=0.558, p=0.092$ with nonprofits) and for-profits and nonprofits are statistically indistinguishable on the dimension $(b=0.126, p=0.580)$. The substantive impact of this variable is notable (see Table 3). A one unit increase in trust increases the probability of the vendor being identified as another government by 8.1 percentage points, which represents a $73.4 \%$ increase in the probability of the vendor being of such status. ${ }^{9,10}$

As expected, nonprofits are clearly separated from the other two vendor types in terms of Community ties and Measurement difficulty. Nonprofits are considered notably more connected to their communities than either for-profits or other governments $(b=1.314, p=0.000$ and $b=-0.700, p=0.004$, respectively). And the impact of this variable is also sizable-a one unit increase in community ties is associated with a 27.8 percentage point (or $105.6 \%$ ) increase in the probability that the vendor is a nonprofit, which makes this measure one of the most dominant indicators of nonprofit status in the model. Although community ties appear to a strong differentiator between government and for-profit vendors, Table 3 indicates that the impact of this variable on other government status is fairly meager. Another prevailing indicator for predicting 
Table 3. Impacts for Statistically Significant Variables.

\begin{tabular}{|c|c|c|c|}
\hline Independent variables & New probability & $\Delta$ probability & $\% \Delta$ probability \\
\hline \multicolumn{4}{|l|}{ Variables of interest } \\
\hline \multicolumn{4}{|l|}{ Trust } \\
\hline For-profit & 0.548 & -0.079 & -12.556 \\
\hline Nonprofit & 0.261 & -0.002 & -0.794 \\
\hline Other government & 0.191 & 0.081 & 73.369 \\
\hline \multicolumn{4}{|l|}{ Community ties } \\
\hline For-profit & 0.346 & -0.280 & -44.761 \\
\hline Nonprofit & 0.541 & 0.278 & 105.629 \\
\hline Other government & 0.112 & 0.002 & 2.100 \\
\hline \multicolumn{4}{|l|}{ Measurement difficulty } \\
\hline For-profit & 0.498 & -0.129 & $-20.58 \mid$ \\
\hline Nonprofit & 0.402 & 0.139 & 52.745 \\
\hline Other government & 0.100 & -0.010 & -9.025 \\
\hline \multicolumn{4}{|l|}{ Asset specificity } \\
\hline For-profit & 0.324 & -0.303 & -48.314 \\
\hline Nonprofit & 0.539 & 0.276 & 104.637 \\
\hline Other government & 0.137 & 0.027 & 24.697 \\
\hline \multicolumn{4}{|l|}{ Few vendors } \\
\hline For-profit & 0.528 & -0.098 & -15.677 \\
\hline Nonprofit & 0.348 & 0.084 & 32.000 \\
\hline Other government & 0.124 & 0.014 & 12.683 \\
\hline \multicolumn{4}{|l|}{ Citizen interest } \\
\hline For-profit & 0.774 & 0.148 & 23.596 \\
\hline Nonprofit & 0.128 & -0.135 & -51.358 \\
\hline Other government & 0.097 & -0.013 & -11.456 \\
\hline \multicolumn{4}{|l|}{ Contract features } \\
\hline For-profit & 0.498 & -0.129 & -20.583 \\
\hline Nonprofit & 0.241 & -0.022 & -8.339 \\
\hline Other government & 0.261 & 0.151 & 137.109 \\
\hline \multicolumn{4}{|c|}{ Contacts and coordination } \\
\hline For-profit & 0.621 & -0.006 & -0.897 \\
\hline Nonprofit & 0.288 & 0.025 & 9.386 \\
\hline Other government & 0.091 & -0.019 & -17.347 \\
\hline \multicolumn{4}{|l|}{ Controls } \\
\hline \multicolumn{4}{|l|}{ Population 2008} \\
\hline For-profit & 0.594 & -0.033 & -5.260 \\
\hline Nonprofit & 0.339 & 0.075 & 28.595 \\
\hline Other government & 0.068 & -0.042 & -38.466 \\
\hline \multicolumn{4}{|l|}{ County } \\
\hline For-profit & 0.697 & 0.071 & 11.293 \\
\hline Nonprofit & 0.251 & -0.012 & -4.746 \\
\hline Other government & 0.052 & -0.058 & -52.931 \\
\hline
\end{tabular}

Note: "Impact" is calculated as follows:A baseline probability is determined for each dependent variable category by setting the 5-point variables at their median values, quasi-continuous variables at their means, and the dummies such that each case represents a city (as opposed to county) with a council-manager form of government. This leads to baseline probabilities of $p_{\mathrm{fp}}=0.627, p_{\mathrm{np}}=0.263$, and $p_{\mathrm{og}}=0.110$, which compare favorably with the true probabilities in the dataset $\left(p_{\mathrm{fp}}=0.636\right.$, $p_{\mathrm{np}}=0.269, p_{\mathrm{og}}=0.096$ ). Each variable, in turn, is then increased in value (dummies and 5 -points by one increment and quasicontinuous by one standard deviation), while holding all other variables constant, and new probabilities are calculated. The appropriate comparisons are then made between the new and baseline probabilities. 
nonprofit status is the measurement difficulties associated with the services vendors deliver. Nonprofits are clearly distinguished from other governments and for-profits $(b=-0.238$, $p=0.033$ and $b=0.300, p=0.002$, respectively) on this metric - they are preferred for the production of difficult-to-evaluate services. Other governments and for-profits are indistinguishable in this regard. Considering that the majority of nonprofit vendors are human service agencies and human services are in general more challenging to assess in terms of determining quality and effectiveness, this finding makes sense. Other governments, on the other hand, deliver a more even mix of soft (e.g., public health, mental health, elderly services, etc.) and hard (e.g., bus systems, water distribution, sewage treatment, etc.) services in our sample.

Asset specificity also significantly differentiates between the sectors. Nonprofits are associated with the highest levels of asset specificity likely owing to their tendency to deliver assetspecific, customized services to niche populations. However, for-profits are associated with the lowest levels of asset specificity. The substantive impact of this variable is also impressive with a one unit increase associated with a $104.6 \%$ increase in the likelihood the vendor is a nonprofit and a $48.3 \%$ decrease in the probability it is a for-profit.

Our market measure, Few vendors, is only helpful in distinguishing between for-profit and nonprofit vendors. Nonprofits, not surprisingly, tend to compete in less robust markets. However, the impact of this variable is rather moderate with the largest result being a $32 \%$ increase in the likelihood of the vendor being a nonprofit when this variable is increased by one unit.

Although Citizen interest is helpful in identifying vendor ownership, the findings do not conform to expectations. Contracting governments are not statistically more likely to choose public contractors over for-profits $(b=-0.649, p=0.207)$. Furthermore, they appear to eschew nonprofits when dealing with high interest services, contrary to our hypothesis $(b=-1.814, p=0.000)$. Both for-profits and other government contractors are likely vendors in such instances. The substantive impact of this variable appears to be relatively moderate - a one unit increase is associated with a $23.6 \%$ increase in the likelihood of identifying the vendor as for-profit and about a $51.4 \%$ decrease in the probability that the vendor is a nonprofit.

As for the three contract management variables (Contract features, Contacts and coordination, and Use of discretion in sanctioning), nonprofit and for-profit vendors are not statistically separated on any of these aspects. Taken together, along with the findings about Trust, these results suggest that local contracting practices do not conform to the stereotypical expectations pertaining to vendor ownership. Public managers treat nonprofit and for-profit contractors virtually identically in terms of how formally they write contracts or how frequently they interact with vendors during contract execution and monitoring. Moreover, local managers do not take any of the sectors into consideration when it comes to enforcing sanctions and deciding how much discretion to exercise before invoking penalties if noncompliance occurs. Again, this goes against the theoretical expectation that for-profit vendors will be subject to stricter and more market-like discipline than nonprofit and public organizations.

Meanwhile, local jurisdictions seem to regard public vendors as considerably different from the other sectors in terms of preparing written contracts (Contract features: $b=0.314, p=0.000$ and $b=0.273, p=0.002$ for the for-profit and nonprofit comparisons, respectively). When contracting with other governments, for example, governments seem to be only minimally cautious in that contract terms are generally ambiguous, lacking in specific task definitions and/or sanction clauses. Substantively speaking, this is arguably the most influential variable in the model. Increasing Contract features by one standard deviation raises the likelihood of the vendor being "other government" by 15.1 percentage points, or over 137\% from the baseline. This could be associated with the fact that fellow governments appear to be more trusted than the other sectors because of shared institutional identities and familiarity. As such, there is less need for heavy doses of legalism in contract documents, as it is assumed the vendor knows what needs to be done and can be expected to fulfill its obligations of its own accord. 
Finally, turning to our control variables, there is not a lot going on. Larger jurisdictions, as measured by population size, are more likely to employ nonprofit vendors as opposed to forprofits, which makes sense as such jurisdictions tend to be the ones most commonly providing social services, which in turn, are closely associated with the nonprofit sector. The only other control reaching even marginal levels of significance is County in the for-profit versus other government comparison. The coefficient is negative $(b=-0.861, p=0.064)$, indicating that county governments are less likely than municipalities to use other government as compared with for-profit contractors. This lends support to our assertion that much intergovernmental contracting is of the form of municipalities contracting with county governments to achieve economies of scale. Interestingly, there is no evidence that any of the sectors are advantaged in Performance - none of the coefficients are statistically distinguishable from zero. This goes against the arguments of both market advocates such as Savas (2000), who claim the profit motive should trigger superior performance, and those who claim nonprofits may excel in quality service delivery. Generally speaking, the contracting governments in our sample are fairly satisfied with their vendors across the board. For-profits and nonprofits each averaged around 3.9 on this 5-point, ordered scale, while other governments averaged 4.1.

\section{Conclusions and Implications}

The main purpose of this study is to comprehensively investigate the vendor ownership-related contracting characteristics identified in the literature. Our findings call for a careful reexamination of the conventional understanding as to the exact role vendor ownership plays in local contracting practice. In our sample, the factors that differentiate the sectors from one another are multidimensional in nature and do not neatly coincide with existing theoretical expectations. For instance, local governments do not regard their nonprofit partners as particularly more trustworthy than for-profit vendors nor appear to manage them in divergent manners simply based on sectoral affiliation, which may indicate that local managers are pragmatic (Hefetz \& Warner, 2012) and perhaps "smart buyers" (Kettl, 1993) who "avoid the sector-related stereotypes" (Amirkhanyan, 2010, p. 750). This does not mean that governments do not see them differently. In fact, they conceive of nonprofits as being much closer to their communities, which could explain the heavy use of this type of vendor for the delivery of community-based human services. Local governments also recognize difficulties and challenges associated with evaluating the quality of human services that nonprofits typically deliver (see Smith Lipsky, 1993 for related discussions) and the often limited and semi-monopolistic nature of the markets in which they operate. What is interesting, however, is that governments' apparent awareness about these tenets has little to do with how much they trust their vendors. This seeming disconnect between the transaction cost natures of services and underlying trust issues is important because it raises questions as to the validity of the sector-based trustworthiness proposition frequently adopted in the literature to explain vendor selection or other contract management behaviors. A number of scholars raise similar concerns on this matter and call for a careful examination of the underlying motives and associated behaviors of nonprofits in contracting (Amirkhanyan, 2010; Brooks, 2005; Heinrich, 2000; Van Slyke, 2003; Weisbrod, 1988).

Although the findings regarding governmental service providers require caution in their interpretations and implications because of the small number of such vendors (32) found in this study, the largely hands-off ex ante control mechanism (i.e., written contract features) adopted for these types of vendors is noteworthy. The existing literature would argue that a high level of goal congruence between principal and agent governments enables public managers to adopt laissez-faire approaches toward public contractors, yet the same mission alignment assumption does not yield an identical effect on managing nonprofits in our sample. Recent studies exploring government-to-government 
contracting suggest a broader and more complex set of commonalities that governments might share with their other government contractors, but not so much with private, nonprofit organizations, such as political and administrative accountability structures, internal monitoring procedures, and performance measures (Brown, 2008; Marvel \& Marvel, 2007; Warner \& Hefetz, 2002). Perhaps, this finding highlights our need to reexamine the role of the goal congruence dimension as it does not sufficiently differentiate the sectors and does not effectively assist us in explaining what management strategies public managers adopt toward each vendor type and why.

In conclusion, future research should expand the scope of its inquiries about vendor ownership beyond the goal congruence-trust assumptions mainly derived from the sectors' legal and organizational constraints. Scholars must investigate a broader range of service, organizational, political, and technological factors and take them into consideration when examining what really matters in building trusting relationships or developing effective strategies to manage vendors. For example, whether for-profit vendors have previously earned positive reputations or nonprofits are accredited by credible agencies and/or have sufficient service and financial capacities might be more important than their ownership status, per se, regarding whether to rely on these service providers. The content of monitoring and, to a degree, its intensity might be determined by the technological complexities and measuring difficulties associated with the services rather than vendors' sectoral affiliations. This does not mean that sectors do not matter. Rather, we simply call for more comprehensive and refined research on the role played by vendor ownership.

\section{Appendix A}

\section{List of Services Included in the Analyses}

- Residential solid waste collection

- Solid waste disposal

- Tree trimming and planting on public rights of way

- Street repair

- Animal control/shelter

- Operation of parking lots and garages

- Traffic sign/signal installation/maintenance

- Commercial solid waste collection

- Street/parking lot cleaning

- Operation/maintenance of bus transit system

- Recycling

- Operation/maintenance of paratransit system

- Sewage collection and treatment

- Snow plowing/sanding

- Parking meter maintenance and collection

- Disposal of sludge

- Pest control

- Water treatment

- Inspection/code enforcement

- Disposal of hazardous materials
- Operation of mental health/mental retardation programs and facilities

- Program for the elderly

- Drug and alcohol treatment program

- Public health program

- Workforce development/job training program

- Child welfare program

- Jail health services

- Homeless shelter

- Child care

- Jail operation 


\section{Appendix B}

\section{Measures Used in the Analysis}

\begin{tabular}{ll}
\hline Vendor type & Three-point categorical measure which identifies \\
(a) "For-profits" & (b) "Nonprofits" \\
(c) "Other governments" & A 5-point ordinal scale with I indicating "if not watched, it would not be surprising \\
for this vendor to cut corners" and 5 indicating "we trust this vendor to fulfill its \\
obligations even when it is not being watched." \\
Community \\
A 5 -point ordinal scale with I indicating "this vendor does not have strong ties to our \\
community" and 5 indicating "this vendor has strong ties to our community." \\
difficulty \\
An additive scale consisting of two 5-point ordinal indicators, thus the variable ranges \\
from 2 to I0 (Cronbach's alpha = 0.798), such that \\
(a) For the first variable, I indicates "tasks are standardized and easily defined" and 5 \\
indicating "tasks require customization and are not easy to define." \\
(b) For the second variable, I indicates "performance and service quality are easy to \\
measure" and 5 indicating "performance is hard to measure and service quality is \\
hard to determine."
\end{tabular}

Asset specificity Brown and Potoski's (2003a) 5-point scale with I indicating the lowest levels of asset specificity and 5 the highest (see the appendix in their study for detailed information regarding the measurement of the variable).

Few vendors A 5-point ordinal scale with I indicating "there are many vendors available in the market to replace the incumbent" and 5 indicating "there are very few vendors in the market to replace the incumbent."

Citizen interest This measure is borrowed from Hefetz and Warner (2012, p. 309).A 5-point ordinal scale with I indicating "low" and 5 "high" on the following statement to local public managers: "For many services, the public is not interested in how the service is delivered, just that it is timely and of good quality. But for some services the public has a high degree of interest in the process of service delivery and opportunities for participation must be preserved."

Contract An additive scale consisting of three 5-point ordinal indicators, thus the variable ranges features from 3 to 15 (Cronbach's alpha $=0.753$ ), such that

(a) For the first variable, I indicates "contract is rebid regularly, regardless of incumbent performance" and 5 indicates "contract is not rebid unless incumbent discontinues service or has serious problems."

(b) For the second variable, I indicates "contract explicitly spells out deliverables, performance measures, and reporting requirements" and 5 indicates "contract does not cover detailed requirements, but contract terms and obligations are mutually understood."

(c) For the third variable, I indicates "contract explicitly lays out sanction clauses that contain specific and detailed penalties" and 5 indicates "contract does not have explicit sanction clauses that detail penalties."

Contacts and A 5-point ordinal scale with I indicating "contacts and coordination with the vendor are coordination rare during contract implementation" and 5 indicating "contacts and coordination with the vendor are very common during contract implementation."

Use of A 5-point ordinal scale with I indicating "sanctions are imposed as written in the discretion contract with little discretion or negotiation" and 5 indicating "negotiation often takes in sanctioning place without formal sanctioning and contract terms may be altered as a result."

Professional A dichotomous variable that scores I for council-manager (cities) and counciladministrator administrator (counties) forms of government.

Population 2008 U.S. census population estimates (transformed to millions so variable scales are compatible).

County A dichotomous variable that scores I for county government and 0 otherwise.

Performance A 5-point ordinal scale with I indicating "this vendor has been performing very much below expectations" and 5 indicating "this vendor has been performing very much above expectations."

Note:The 5-point scales referenced above represent the actual questions posed to the respondents. For each service for which they responded, they were asked to mark on a number line what they felt to be the appropriate answer ranging between the "I" and " 5 " options listed above. 


\section{Appendix C}

Comparison of Characteristics of the Municipalities in the Sample With the UnitedStates, Overall ICMA List, and Requested ICMA List ${ }^{a}$

\begin{tabular}{|c|c|c|c|c|}
\hline Characteristic & United States (\%) & $\begin{array}{c}\text { Overall ICMA } \\
\text { list / (\%) }\end{array}$ & $\begin{array}{c}\text { Requested ICMA } \\
\text { list / (\%) }\end{array}$ & Sample (\%) \\
\hline \multicolumn{5}{|l|}{ Population } \\
\hline Less than 10,000 & $86.6^{\mathrm{a}}$ & 54.7 & 0.0 & 0.0 \\
\hline 10,000 to 49,999 & 10.4 & 36.2 & 28.1 & 21.1 \\
\hline 50,000 to 249,999 & 2.6 & 8.2 & 64.5 & 73.7 \\
\hline 250,000 or greater & 0.3 & 0.9 & 7.4 & 5.3 \\
\hline \multicolumn{5}{|l|}{ Region } \\
\hline Northeast & $13.2^{\mathrm{b}}$ & $21.1^{\mathrm{c}}$ & 19.6 & 13.5 \\
\hline North Central & 32.5 & 30.8 & 24.6 & 20.5 \\
\hline South & 35.8 & 33.5 & 25.1 & 29.8 \\
\hline West & 18.5 & 14.7 & 30.7 & 36.3 \\
\hline \multicolumn{5}{|l|}{ Metro Status } \\
\hline Central & d & $d$ & 43.7 & 40.9 \\
\hline Suburban & d & $d$ & 51.4 & 55.0 \\
\hline Independent & d & d & 5.0 & 4.1 \\
\hline \multicolumn{5}{|l|}{ Form of Government } \\
\hline Mayor-Council & d & $d$ & 34.7 & 17.5 \\
\hline Council-Manager & $d$ & d & 62.6 & 81.3 \\
\hline Commission & d & d & 1.6 & 1.2 \\
\hline \multirow[t]{2}{*}{ Town Meeting } & d & d & I.I & 0.0 \\
\hline & $(N=35,933)$ & $(N=7,23 I)$ & $(N=925)$ & $(N=128)$ \\
\hline
\end{tabular}

${ }^{a}$ Information on U.S. jurisdictions were available only for municipalities and not counties. Therefore, we dropped counties from our comparison. The municipality/county breakdown for each of the categories is as follows: U.S. - 35,933/3034 (U.S. Census Bureau 2002); ICMA List (Overall) -7,23I/3039 (ICMA's academic researcher's order form, available from ICMA); ICMA list (Requested)—925/I075 (authors' calculations); Sample—128//20 (authors' calculations).

bESRI (2003).

'The ICMA order sheet did not break down region by municipalities and counties, so the numbers reported here are for the aggregate.

${ }^{\mathrm{d}}$ Not available.

\section{Declaration of Conflicting Interests}

The author(s) declared no potential conflicts of interest with respect to the research, authorship, and/or publication of this article.

\section{Funding}

The author(s) received no financial support for the research, authorship, and/or publication of this article.

\section{Notes}

1. The author later qualifies this by pointing out that there may be a bias toward such responses as it is important for public managers to avoid showing favoritism in their vendor relations.

2. We originally sent the surveys directly to individuals named as the "chief administrative officer" for the jurisdiction in question, as listed in the ICMA contact list. This was not an effective strategy and in the 
follow-up mailings, we sent packets to the generic title "chief administrative officer" (CAO). This improved our response rate. In the cover letter, we asked the CAOs to fill out our surveys or forward them to appropriate persons if they felt they were unable/unqualified to fill them out themselves. We also requested identifier information from the respondents. About one-quarter of respondents refused to identify themselves, but for the 200 we have information for, after grouping the myriad reported job titles into four distinct categories, we find that $115(57.5 \%)$ are city or county managers, their deputies, or work directly in their offices; $74(37.0 \%)$ are department heads, their deputies, or staff; seven (3.5\%) are elected officials or their staff; and four (2.0\%) are city/county clerks.

3. Respondents were specifically asked to mark a number line running from 1 to 5 , which allowed some to choose midrange values, such as 3.5 . Such choices were not overly common and only accounted for about $3 \%$ of responses for the questions included in the analysis. Also, the only midrange options marked were midpoints. Therefore, our 5-point scales actually contain up to nine ordered response categories.

4. Our response rate is lower than preferred, but as outlined above, every effort was made to increase it. We suspect our survey was, to some extent, a victim of the current economic climate in which local governments are dealing with unprecedented budget shortfalls leading to difficulty in maintaining staffing levels, among other issues, that might make it more difficult/unlikely they would have the resources or be willing to make an effort to fill out our survey. That said, our rate compares favorably with some recent research in this area (e.g., Hefetz \& Warner's [2012] rate is 7.5\%). And, the number of unique jurisdictions included in our sample also fairs well (e.g., $N=167$ for Hefetz \& Warner [2012] and $N=137$ for Marvel \& Marvel [2007]).

5. It should be noted that although we have no definitive information on the distribution of forms of governments in the United States, the requested ICMA list likely also has a disproportionately large number of council-manager jurisdictions. For example, ICMA's most recent municipal (2006) and county (2007) form of government surveys found $54.5 \%$ and $29.6 \%$ council-manager governments, respectively.

6. Readers interested in more information on this model are directed to Long (1997).

7. Hausman tests for IIA are indeterminant. A series of Hausman-like tests conducted using the "suest" command in Stata 10.1 shows that no parameter estimates are significantly affected, at conventional levels, when the models are rerun with suppressed dependent variable categories. As the efficacy of such tests has been cast into doubt (Cheng \& Long, 2007), we also ran the model as a multinomial probit as a check. The results are identical regarding statistical inference. There are also no notable differences in the predicted probabilities generated by the competing models. Since recent research (Kropko, 2008) indicates that multinomial logit may be the more robust model, even in the face of severe IIA, we choose to report the multinomial logit results. Interested readers can contact the authors for more information.

8. That is, the null model correctly predicts $63.6 \%$ of the cases. Our model correctly predicts $80.3 \%$ of cases. The proportional reduction in error is then $([80.3-63.6] / 63.6) \times 100=26.3$.

9. It is important to point out that the baseline probability of observing another government vendor is somewhat small, $11.0 \%$, which means that fairly small percentage point changes can lead to rather dramatic changes in overall probability.

10. See the note at the bottom of Table 3 for an explanation of how the impacts are calculated.

\section{References}

Amirkhanyan, A. (2010). Monitoring across sectors: Examining the effect of nonprofit and for-profit contractor ownership on performance monitoring in state and local contacts. Public Administration Review, $70,742-755$. 
Andrews, R., \& Entwistle, T. (2010). Does cross-sectoral partnership deliver? An empirical exploration of public service effectiveness, efficiency, and equity. Journal of Public Administration Research and Theory, 20, 679-701.

Bartels, L. M. (1991). Constituency opinion and congressional policy making: The Reagan defense buildup. American Political Science Review, 85, 457-474.

Bel, G., \& Fageda, X. (2006). Between privatization and intermunicipal cooperation: Small municipalities, scale economies, and transaction costs. Urban Public Economics Review, 6, 13-31.

Bellah, R. N., Madson, R., Sullivan, W. M., Swidler, A., \& Tipton, S. M. (1985). Habits of the heart: Individualism and commitment in American life. New York, NY: Harper and Row.

Berger, P. L., \& Neuhaus, R. J. (1977). To empower people: The role of mediating structures in public policy. Washington, DC: American Enterprise Institute.

Billis, D., \& Glennester, H. (1998). Human services and the voluntary sector: Towards a theory of comparative advantage. Journal of Social Policy, 27(1), 79-98.

Boris, E. T., \& Steuerle, C. E. (2006). Scope and dimensions of the nonprofit sector. In W. W. Powell \& R. Steinberg (Eds.), The non-profit sector: A research handbook, (2nd ed., pp. 66-88). New Haven, CT: Yale University Press.

Brewer, G. A., \&. Selden, S. C. (1998). Whistle blowers in the federal civil service: New evidence of the public service ethic. Journal of Public Administration Research and Theory, 8, 413-439.

Brooks, A. C. (2005). What do nonprofit organizations seek? (and why should policymakers care?) Journal of Policy Analysis and Management, 24, 543-558.

Brown, T. (2008). The dynamics of government-to-government contracts. Public Performance \& Management Review, 31, 364-386.

Brown, T. L., \& Potoski, M. (2003a). Transaction costs and institutional explanations for government service production decisions. Journal of Public Administration Research and Theory, 13, 441-468.

(2003b). Contract-management capacity in municipal and county governments. Public Administration Review, 63, 153-164.

. (2005). Transaction costs and contracting: The practitioner perspective. Public Performance \& Management Review, 28, 326-351.

Brown, T., Potoski, M., \&. Slyke, D. V. (2006). Managing public service contracts: Aligning values, institutions, and markets. Public Administration Review, 66, 323-331.

Carr, J. B., LeRoux, K., \& Shrestha, M. (2009). Institutional ties, transaction costs, and external service production. Urban Affairs Review, 44, 403-427.

Cheng, S., \&. Long, J. S (2007). Testing for IIA in the multinomial logit model. Sociological Methods and Research, 35, 583-600.

DeHoog, R. H. (1984). Contracting out for human services: Economic, political, and organizational perspectives. Albany, NY: State University of New York Press.

Dunleavy, P. J., \& Hood, C. (1994). From old public administration to new public management. Public Money and Management, 14(3), 9-16.

Environmental Systems Research Institute (2003). ESRI data \& maps DVD. Redlands, CA: Author.

Ferris, J., \&. Graddy, E. (1986). Contracting out: For what? With whom? Public Administration Review, 46, 332-344.

(1991). Production costs, transaction costs, and local government contractor choice. Economic Inquiry, 29, 541-554.

Hall, P. (1989). Business giving and social investment in the United States. In R. Magat (Ed.), Philanthropic Giving: Studies in Varieties and Goals (pp. 221-245). New York, NY: Oxford University Press.

Hansmann, H. (1987). Economic theories of nonprofit organization, In W. Powell (Ed.), The nonprofit sector: A research handbook (pp. 27-42). New Haven, CT: Yale University Press.

Heckman, J. J.,. Heinrich, C., \& Smith, J. (2002). The performance of performance standards. Journal of Human Resources, 37, 778-811. 
Hefetz, A., \& Warner, M. (2012). Contracting or public delivery? The importance of service, market and management characteristics. Journal of Public Administration Research and Theory, 22(2), 289-317.

Heinrich, C. J. (2000). Organizational form and performance: An empirical investigation of nonprofit and for-profit job training service providers. Journal of Policy Analysis and Management, 19, 233-261.

(2007). False or fitting recognition? The use of high performance bonuses in motivating organization achievements. Journal of Policy Analysis and Management, 26, 281-304.

Hirsch, W. Z. (1991). Privatizing government services: An economic analysis of contracting out by local governments. Los Angeles, CA: Institute of Industrial Relations Publication Center, University of California.

Holmstrom, B., \& Milgrom, P. (1991). Multitask principal-agent analyses: Incentive contracts, asset ownership and job design. Journal of Law and Economics, 7(Special issue), 24-52.

Hood, C. (1991). A public management for all seasons? Public Administration, 69(1), 3-19.

Kettl, D. (1993). Sharing power: Public governance and private markets. Washington, DC: Brookings Institution.

Kropko, J. (2008, April 3-6). Choosing between multinomial logit and multinomial probit models for analysis of unordered choice data. Paper presented at the annual meeting of the Midwest Political Science Association, Chicago, IL.

Lamothe, M., \& Lamothe, S. (2009). Beyond the search for competition in social service contracting: Procurement, consolidation, and accountability. American Review of Public Administration, 39, 164-188.

Lamothe, M., \& Lamothe, S. (2010). Competing for what? Linking competition to performance in social service contracting. American Review of Public Administration, 40, 326-350.

Lamothe, S., \& Lamothe, M. (2006). The dynamics of local service delivery arrangements and the role of nonprofits. International Journal of Public Administration, 29, 769-797.

Lamothe, S., Lamothe, M., \& Richard, C. F. (2008). Examining local government service delivery arrangements over time. Urban Affairs Review, 44(1), 27-57.

Leete, L. (2006). Work in the nonprofit sector. In W. W. Powell \& R. Steinberg (Eds.), The non-profit sector: A research handbook (pp. 159-179). New Haven, CT: Yale University Press.

Levin, J., \& Tadelis, S. (2010). Contracting for government services: Theory and evidence from U.S. cities. Journal of Industrial Economics, 58, 507-541.

Light, P. C. (2004). Sustaining nonprofit performance: The case for capacity building and the evidence to support it. Washington, DC: Brookings Institution Press.

Long, J. S. (1997). Regression models for categorical and limited dependent variables. Thousand Oaks, CA: Sage.

Lowery, D. (1998). Consumer sovereignty and quasi-market failure. Journal of Public Administration Research and Theory, 8(2), 137-173.

Marvel, M. K., \& Marvel, H. P. (2007). Outsourcing oversight: A comparison of monitoring for in-house and contracted services. Public Administration Review, 67, 521-530.

. (2008). Government-to-government contracting: Stewardship, agency, and substitution. International Public Management Journal, 11, 171-192.

. (2009). Shaping the provision of outsourced public services: Incentive efficacy and service delivery. Public Performance \& Management Review, 33, 183-213.

Milward, B. H., \& Provan, K. G. (2000). Governing the hollow state. Journal of Public Administration Research and Theory, 10, 359-379.

Moe, R. C. (1996). Managing privatization: A new challenge to public administration. In G. Peters \& B. A. Rockman (Eds.), Agenda for excellence 2: Administering the State (pp. 135-148). Chatham, NJ: Chatham House.

Osborne, D., \& Gaebler, T. (1992). Reinventing government: How the entrepreneurial spirit is transforming the public sector. Reading, MA: Addison-Wesley. 
Rainey, H. G. (1982). Reward preferences among public and private managers: In search of the service ethic. American Review of Public Administration, 16, 288-302.

Salamon, L. M. (1995). Partners in public service: Government-nonprofit relations in the modern welfare state. Baltimore, MD: Johns Hopkins University Press.

Savas, E. S. (1987). Privatization: The key to better government. Chatham, NJ: Chatham House. . (2000). Privatization and public-private partnerships. New York, NY: Chatham House.

Schlesinger, M., \& Gray, B. H. (2006). Nonprofit organizations and health care: Some paradoxes of persistent scrutiny. In W. W. Powell \& R. Steinberg (Eds.), The non-profit sector: A research handbook (2nd ed., pp. 378-414). New Haven, CT: Yale University Press.

Sclar, E. (2000). You don't always get what you pay for: The economics of privatization. Ithaca, NY: Cornell University. Press.

Smith, S. R., \& Lipsky, M. (1993). Nonprofit for hire: The welfare state in the age of contracting. Cambridge, MA: Harvard University. Press.

Stein, R. M. (1990). Urban alternatives: Public and private markets in the provision of local services. Pittsburgh, PA: University of Pittsburgh Press.

Steinberg, R. (2006). Economic theories of nonprofit organizations. In W. W. Powell \& R. Steinberg (Eds.), The non-profit sector: A research handbook (2nd ed., 117-139). New Haven, CT: Yale University Press.

U.S. Census Bureau. (2002). Census of Governments. Volume 1, number 1, government organization, GCO2(1)-1. Washington, DC: U.S. Government Printing Office.

Van Slyke, D. M. (2003). The mythology of privatization in contracting for social services. Public Administration Review, 63, 296-315.

(2007). Agents or stewards: Using theory to understand the government-nonprofit social service contracting relationship. Journal of Public Administration Research and Theory, 17, 157-187.

Warner, M. (2006). Inter-municipal cooperation in the U.S.: A regional governance solution? Urban Public Economics Review, 6, 221-240.

Warner, M., \& Hebdon, R. (2001). Local government restructuring: Privatization and its alternatives. Journal of Policy Analysis and Management, 20, 315-336.

Warner, M., \& Hefetz, A. (2002). Applying market solutions to public services: An assessment of efficiency, equity, and voice. Urban Affairs Review, 38, 70-89.

Weisbrod, B. A. (1988). The nonprofit economy. Cambridge, MA: Harvard University Press.

White, H. (1980). A heteroscedasticity-consistent covariance matrix and a direct test for heteroscedasticity. Exonometrica, 48, 817-838.

Williamson, O. E. (1985). The economic institutions of capitalism. New York, NY: Free Press.

Worth, M. J. (2009). Nonprofit management: Principles and practice. Thousand Oaks, CA: Sage.

Young, D. (2006). Complementary, supplementary, or adversarial? Nonprofit-government relations. In E. T. Boris \& C. E. Steuerle (Eds.), Nonprofits \& government: Collaboration \& conflict (pp. 37-79). Washington, DC: Urban Institute Press.

\section{Author Biographies}

Scott Lamothe is an assistant professor in the department of political science at the University of Oklahoma. His current research focuses on contracting decisions and the role of competition. His recent work has been published in the Journal of Public Administration Research and Theory, American Review of Public Administration, and Urban Affairs Review.

Meeyoung Lamothe is currently an associate professor at the University of Oklahoma. Her research interests include local alternative service delivery arrangements, social service contracting, and nonprofit management. Her recent publications may be found in the Journal of Public Administration Research and Theory, International Journal of Public Administration, and American Review of Public Administration. 